\title{
NURSES' KNOWLEDGE REGARDING THE HANDLING OF THE TOTALLY-IMPLANTED VENOUS ACCESS DEVICE ${ }^{1}$
}

\author{
Nayara Nárley Pires², Christiane Inocêncio Vasques ${ }^{3}$
}

\footnotetext{
${ }^{1}$ End of Course Paper, presented to the Multi-Professional Residency in Health Program at the University Hospital of Brasília (HUB), area of specialization Nursing in Oncology Care, 2013.

2 M.Sc. student in Health Sciences. Specialist in Oncology Nursing at HUB. Brasília, Federal District, Brazil. Email: nayaranarley@ hotmail.com

${ }^{3}$ Ph.D. in Nursing. Adjunct Professor of the Department of Nursing in the Faculty of Health Sciences at the University of Brasilia (UnB). Brasília, Brazil. Email: chvasques@unb.br
}

\begin{abstract}
In the light of nurses' questions regarding the handling of the totally-implanted venous access device, this study aimed to evaluate these professionals' knowledge. This is a descriptive study with a qualitative approach, whose sample was made up of 28 nurses working on the Internal Medicine ward and in the Emergency Room. The study was undertaken in two stages: interviewing, to evaluate knowledge regarding the handling of the implanted port; and an integrative review to clarify the doubts identified. The results indicated that the nurses' knowledge was inadequate regarding when to use the implanted port, its purpose, the puncture technique, maintenance and handling. It is concluded that the knowledge of the subjects evaluated is inadequate, and that it is necessary for these professionals' clinical skills to be standardized and for them to receive theoretical-practical training.
\end{abstract}

KEYWORDS: Catheters. Catheterization, central venous. Nursing care. Indwelling catheter. Oncology nursing.

\section{CONHECIMENTO DE ENFERMEIROS ACERCA DO MANUSEIO DE CATETER TOTALMENTE IMPLANTADO}

RESUMO: Frente aos questionamentos de enfermeiros acerca do manuseio do cateter totalmente implantado, teve-se como objetivo avaliar o conhecimento destes profissionais. Trata-se de estudo descritivo com abordagem qualitativa, cuja amostra foi composta por 28 enfermeiros atuantes na enfermaria de clínica médica e no Centro de Pronto Atendimento. O estudo foi desenvolvido em duas etapas: entrevista para avaliação do conhecimento sobre o manuseio do cateter totalmente implantado; e revisão integrativa para esclarecer as dúvidas identificadas. Os resultados apontaram déficit de conhecimento dos enfermeiros sobre indicação e finalidade do cateter, técnica de punção, manutenção e manuseio. Conclui-se que o conhecimento dos sujeitos avaliados é deficitário, havendo necessidade de padronização das condutas e capacitação teórico-prática destes profissionais.

PALAVRAS CHAVE: Cateteres. Cateterismo venoso central. Cuidados de enfermagem. Cateteres de demora. Enfermagem oncológica.

\section{CONOCIMIENTO DE LOS ENFERMEROS SOBRE EL MANEJO DEL CATÉTER TOTALMENTE IMPLANTADO}

\begin{abstract}
RESUMEN: Frente a consultas de enfermería sobre el manejo del catéter en pleno funcionamiento, se evaluaron los conocimientos de estos profesionales. Se trata de un estudio descriptivo con un enfoque cualitativo, cuya muestra estuvo conformada por 32 enfermeras que trabajan en la sala de Medicina Interna y el Centro de Atención de Emergencias. El estudio se realizó en dos etapas: entrevista para evaluar su conocimiento sobre el manejo del catéter totalmente implantado; e revisión integrativa para aclarar las dudas identificadas. Los resultados mostraron un déficit de conocimiento de las enfermeras sobre la indicación y el propósito de la sonda, técnica de punción, mantenimiento y manejo. Llegamos a la conclusión de que el conocimiento de los sujetos evaluados es deficitario, lo que requiere la estandarización de conductas y formación teórico-práctico de estos profesionales.
\end{abstract}

PALABRAS CLAVE: Catéteres. Cateterismo venoso central. Atención de enfermería. Catéteres de permanencia. Enfermería oncológica. 


\section{INTRODUCTION}

Patients who receive prolonged treatment and need constant use of the venous network are likely to present, at some point, peripheral vascular weakness. Cancer patients stand out among these, as chemotherapy treatment causes this condition. In these cases, it is necessary to select resources which viabilize safe, long term venous access, which can be obtained through use of the central venous catheter. ${ }^{1}$

In the area of Oncology, the totally implanted venous access device (TIVAD) (also known as the implanted port) is an option for adult patients, as it ensures safety in the long term administration of intravenous medications. This catheter is indicated for those patients who shall receive long-term chemotherapy (over six months) over multiple cycles, the infusion of vesicant chemotherapy agents, or agents which lead to severe medullary aplasia, chemotherapy in which the infusion time is over eight hours, patients who underwent bilateral mastectomy, and patients with intense lymphedema, as well as obese patients with difficult venous access. Its insertion requires a surgical procedure, generally undertaken under local anaesthesia. ${ }^{2-3}$

The implantation of this device offers the patients a reduction of the pain and anxiety caused by repeated punctures or venous dissections for receiving the recommended therapy, as well as greater freedom and safety for undertaking their daily activities, which contribute to better quality of life. ${ }^{2}$ The infusion of chemotherapy agents, blood products/blood derivatives and parenteral nutrition is possible through the catheter, as is the collection of blood samples for laboratory tests. ${ }^{4-5}$

The access to the device is made through pushing a non-coring needle through the skin and the silicon rubber membrane of the port chamber, and the main element of the care includes flushing with normal saline solution and heparinization. ${ }^{6}$ Although this is a safe route, some complications related to the use of the implanted port can appear, such as: infection, obstruction, infiltration or leakage, among others. For the device to last longer and to avoid the appearance of these complications, it is necessary for the nurses who work with this device to have technical-scientific knowledge and training for its use, in an articulated and standardized way, this being an activity which must be undertaken exclusively by nurses. ${ }^{7-8}$ Furthermore, continuous education actions must take place regularly, so as to keep the team up-to-date regarding the han- dling techniques and the main care steps relating to the handling of the catheter. ${ }^{2}$

The University Hospital of Brasilia (HUB) has a unit termed the High Complexity Center in Oncology (CACON), which is a center of excellence in cancer care in the Federal District, and which runs on an outpatient basis. Bearing in mind how it runs, when the patients monitored there need emergency or inpatient treatment, they are referred to the Emergency Room (ER) or to the Internal Medicine (IM) ward, respectively. Although the nurses who work in these departments deal with cancer patients on a daily basis, the majority do not have professional training for attending this clientele, which gives rise to innumerable doubts regarding undertaking the procedures specific to this area. The handling of the TIVAD is one of these procedures, as it is undertaken frequently in these areas, given that most of the patients have been fitted with this device. It is emphasized that this fact prompted the undertaking of this study.

As a result, knowing the principal doubts held by the professionals who deal directly with this clientele can guide continuous education actions, with the aim of improving the quality of the nursing care. Therefore, the present study aimed to evaluate the nurses' knowledge regarding the handling of the TIVAD.

\section{MATERIALS AND METHODS}

This is a cross-sectional study, with a descriptive character and a qualitative approach. The study was undertaken in September - October 2012, in the IM and ER departments of the HUB. The workforce of the areas mentioned was made up of 32 nurses. During the period of data collection, however, two were on leave and two declined to participate in the research. As a result, the sample was made up of 28 nurses, for whom the inclusion criteria were: to manage the TIVAD and to accept to participate in the study through signing the Terms of Free and Informed Consent (TFIC). Those with professional experience of less than one year were excluded.

The study was submitted for consideration by the Research Ethics Committee of the Faculty of Medicine of the University of Brasília (UnB), following the precepts established by Resolution CNS N. 196, of 10/10/96, which establishes ethical rules for regulating studies involving human beings. ${ }^{9}$ The study was protocolled under N. 047/2012, and was approved on $17^{\text {th }}$ August 2012. 
The interviews were held in a room in the subjects' workplace and during their shift. Only the interviewer and the subject were present. The guiding question was as follows: what are your main doubts and/or difficulties when you face a patient with a TIVAD? Based on this central question, a number of topics related to the handling of the catheter were raised, should the interviewee not address them, so as to identify possible doubts which did not emerge in answering the main question.

The interviews were recorded, the subjects being identified as I1, I2, I3 etc, in accordance with the order in which the interviews were held, thus preserving the participants' privacy and the confidentiality of the data. The method used for analyzing the data obtained was the system of content analysis ${ }^{10}$. Content analysis is a set of techniques for analyzing communications, which uses systematic and objective procedures for describing the content of the messages, which allow the inference of knowledge relating to the conditions of production of and receiving of these messages. This method is composed of three stages, namely: pre-analysis, exploration of the material, and treatment of the results/interpretation. . $^{10,11}$

The interviews were then transcribed through repeated and interrogative reading of the material, which allowed the arrangement of the set of the information obtained and to grasp the principal doubts indicated by the participants, thus constructing the categories which emerged from the data.

The results obtained in this stage supported the development of the second stage, in which an integrative review of the literature was undertaken, so as to settle the doubts identified in the first stage, which could contribute to the appropriate management of the implanted port.

For this, it was sought to respond to the following guiding question: "What are the principal nursing care steps identified in the scientific literature which must be adopted in the managing of the TIVAD"?

The searches were undertaken in October - December 2012 in the online databases: the Cochrane Library, PubMed/MEDLINE, CINAHL and LILACS. The following search terms were combined: catheterization central venous and antisepsis, implanted catheter and nursing care, catheterization central venous and accessing, catheterization central venous and maintenance. It included studies addressing the managing of the TIVAD in adults, published in English, Portuguese and Spanish, there being no restriction regarding the methodological design of the study or the period of publication of the same. The following were excluded: articles addressing care with the Hickman catheter, the short-term catheter or the peripherally-inserted central catheter (PICC) and those which evaluated the use of catheters for other purposes, such as neonatology, cardiology, hemodialysis and parenteral nutrition.

After the articles selected had been read in full, a data collection instrument ${ }^{12}$ was filled out, containing the identification of the article, the type of study, the content addressed, the results and the level of evidence. For determining the level of evidence, the hierarchical system of evidence was used, ${ }^{13}$ which sets out seven levels: level 1 - systematic review or meta-analysis of the relevant randomized clinical trials; level 2 - evidence obtained from at least one well-designed randomized clinical trial; 3 - well-designed clinical trials without randomization; level 4 - case control studies and cohort studies; 5 - systematic reviews of descriptive studies and qualitative studies; 6 - single descriptive or qualitative studies; and 7- the opinion of authorities and/or a committee of specialists.

\section{RESULTS AND DISCUSSION}

Twenty eight nurses participated in the present study, of whom 10 worked in IM and 18 in ER. Only one of the subjects was male. The mean age was 30 years old and the mean length of professional experience was four years; eight had been qualified for over five years and two of the subjects were specialists in oncology nursing.

Based on the analysis of the interviews it was possible to identify five categories, namely: indications and purpose; the puncture technique; maintenance and handling of the totally implantable venous access device; and the need for standardizing the professional skills.

The categories which emerged from the interviews guided the searches in the databases. 283 articles were identified, of which only 32 met the inclusion criteria. The 251 excluded articles were rejected for the following reasons: short-term central venous catheter $(n=52)$, the semi-implanted catheter $(n=12)$, PICC $(n=15)$, related to parenteral nutrition $(n=19)$, hemodialysis catheter $(n=21)$, related to the implantation technique $(n=20)$, repeated in the databases $(n=18)$ and others $(n=94)$. 
The articles included were published in the period 1994 - 2012. In relation to the level of evidence, the articles were classified as level $1(n=4){ }^{14-}$ ${ }^{17}$ level $2(n=1),{ }^{18}$ level $3(n=1),{ }^{19}$ level $4(n=3),{ }^{20-22}$ level $5(\mathrm{n}=2){ }^{8,23}$ level $6(\mathrm{n}=4)^{24-27}$ and, finally, level $7(n=8) .{ }^{28-35}$ The remaining articles $(n=9)^{36-44}$ were not classified regarding level of evidence, as they were literature reviews without methods and, therefore, are not covered in the hierarchy of evidences adopted.

The results found in the two stages are presented below, in accordance with the categories identified.

\section{Indications and purpose of the Totally- Implanted Venous Access Device}

During the interviews, questions were raised in the nurses' accounts, related to the indications and purpose of this device, as many associated the use of the catheter only with the infusion of the chemotherapy.

[...] I don't know specifically what it is indicated for, but I know that it is used for chemotherapy (I9).

[...] Like, is there is a problem taking a blood sample from the catheter, as it is there because the patient doesn't have any other type of access? Is there a problem in relation to this? And another thing, when the patient enters Emergency Room, can I puncture the port because this really is the access that the patient has, so there is the question: it is a gateway for infection, so should we really puncture this port when we are admitting somebody, or leave it restricted for chemotherapy? Can it be used for blood transfusions? (I1).

The implanted port is indicated for all those patients with difficult peripheral venous access and who will receive prolonged intravenous therapies. ${ }^{14,18,26-27,41}$ The device allows easy access to the venous network and can be used for a variety of purposes, such as the infusion of chemotherapy agents, blood products and medications of all types, such as analgesics and antibiotics, as well as for use with parenteral nutrition and collection of blood samples. ${ }^{8,15,18-19,28,39,41}$ Furthermore, the use of this device offers a lower risk of infection, when compared with the short-term central venous catheter. ${ }^{26,30}$

\section{Puncture technique}

One doubt indicated by the nurses $(n=9)$ was related to the puncture procedure and they confirmed that they did not know how to carry out this technique.
Actually, I have many doubts, in the management at the time of the puncture. I have never undertaken the puncture, I have only watched a nurse doing the puncture in the health center (I14).

Other nurses stated that they know how to undertake the puncture technique; however, they did have specific doubts. Six nurses did not know which type of needle they should use for the puncture. Another doubt indicated was related to the preparation of the skin for the puncture, for which the majority of the interviewees reported using $70 \%$ alcohol. They could not confirm, however, if this is the appropriate solution for this purpose. Subjects also had doubts regarding the angle for introducing the needle when making the puncture $(n=10)$, as well as the confirmation of the correct positioning of the needle after the puncture $(n=8)$.

[...] And in relation to the blood withdraw, when you can't aspirate any, then I am not sure. I know that there might not be this blood withdraw, but I am concerned with whether the patient will feel anything and I remain unsure (I2).

[...] I don't know what the angle is for puncturing, because I have never done the puncture (I20).

[...] But the doubt which I had, and still have, is in relation to the fact of drawing back on the needle or not. This is because sometimes the aspiration of blood is not possible during the puncture. I think it is safer to leave it punctured with a return of blood when you aspirate (I27).

Studies indicate that puncturing the port must

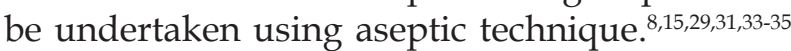
The preparation of the skin is an important step of the puncture technique and, for this, the antiseptic agent of choice is alcoholic chlorhexidine, which is most effective, as the microbicidal action has a residual effect on the skin for longer than alcohol and alcohol-based povidone-iodine ${ }^{26,29,36,38-40}$ It is important to emphasize that the antisepsis of the skin must be undertaken using spiral movements, from inside outwards, starting at the center of the port, and that these must be undertaken at least three times prior to the insertion of the needle. ${ }^{8,31,33}$ A non-coring needle must be used, so as not to harm the silicone of the reservoir, to be introduced at an angle of $90^{\circ}$ until it touches the bottom of the port chamber. ${ }^{8,15,33-34}$

The confirmation of the correct positioning is seen as an important step during the undertaking of the technique of puncturing and is done through carrying out the check for blood return, removing between 2 and $3 \mathrm{ml}$ of blood from the catheter. Another means of confirmation is through the 
free, easy and painless infusion of the solution to be infused. In the event of absence of withdrawal occlusion resistance to the infusion and/or pain in the infusion, the professional must interrupt it and assess the appropriate positioning of the needle. ${ }^{28,32}$

\section{Maintenance of the implanted port}

The maintenance of the patency of the implanted port is also an issue which, according to the subjects, causes doubts. Five nurses showed that they did not know the type of solution used for this purpose; others $(n=15)$ reported doubts regarding the concentration of heparin and, further, in relation to the frequency of heparinization $(n=23)$.

[...] One doubt is the right quantity of heparin which is put in... We have an idea, but we don't know the exact amount... The maintenance is monthly? I'm not sure, because we hardly do it here [...] (I11)

The maintenance of the patency is obtained through flushing (using the push-pause technique), with $20 \mathrm{ml}$ of $0.9 \%$ normal saline after the infusion of any solution and, finally, using a heparin solution to seal the catheter when the catheter is not to be used further on that occasion. ${ }^{23,26,28,34,40,42}$ The dose of heparin can vary from 10 to 1000 IU/ $\mathrm{ml}$, with the concentration of $100 \mathrm{IU} / \mathrm{ml}$, in a volume of $2 \mathrm{ml}$, being the most commonly used. $8,15,28,38$

In relation to the heparinization interval, the manufacturers recommend that this should be undertaken every 30 days. Some retrospective studies, however, state that harm did not occur in the maintenance of patency in catheters which were heparinized at 30 days or 60 days. ${ }^{21,24}$

The subjects also questioned which clinical actions should be taken in the event of obstruction $(\mathrm{n}=15)$. [...] I don't know what solution must be used for clearing obstructions. (I14)

Upon identifying obstruction, one must check the blood return and, following that, attempt to infuse normal saline solution. Emphasis is also placed upon the importance of assessing possible mechanical occlusions, poor positioning of the catheter, kinks, and, even, poor positioning of the needle. In cases of obstruction caused by deposits of fibrin or thrombus, thrombolytic agents have been widely used for clearing obstructions: their administration, however, requires monitoring by a doctor, as there are risks of complications with the use of these drugs. ${ }^{17,35}$

\section{Handling of the implanted port}

Five nurses confirmed that they did not know which substance could be used for undertaking antisepsis when changing the dressing. There were also doubts in relation to the frequency for changing the dressing and needle when there is continuous use of the device.

In Emergency Room, we puncture the port chamber, but a lot of people don't know what the protocols are for doing the dressing. For example: if the puncture is undertaken on a patient today, how long should it be before we change the dressing? [...] I don't know the time for changing the needle either, in the case of a hospitalized patient, I don't really know how long it should stay in. I think it is up to 72 hours. (I2).

I'm not sure about the solution used for the dressing or about changing it, I think it is daily. (I4)

Whenever the catheter is in use, it is recommended that the site of the insertion of the needle should be protected by a dressing, which also has the purpose of stabilizing the needle. ${ }^{31,33-34}$ This dressing must be changed whenever it becomes dirty, damp or loose; these cases excluded, changing is recommended every 48 hours, when sterile gauze is used, and, at the most, every seven days, when a transparent film is used. $8,30,33,40$ The recommended solution is alcoholic chlorhexidine, due to its greater residual effect on the skin. ${ }^{15,36,39}$

Regarding when to change the needle, most studies recommend that the maximum period for a needle to remain in place should be seven days. ${ }^{26,29,30,33}$ One descriptive study assessed 70 patients who had received prolonged infusions of chemotherapy agents, among whom the changing of the needle varied between seven and 50 days. None of the cases presented complications due to the needle's remaining in place. It is concluded that the needle can be kept in for a mean of 28 days. ${ }^{25}$ However, no other study was identified validating this result. Hence, it is suggested that the needle should be changed every seven days.

Upon being questioned regarding the identification of complications, such as infection in the implanted port, and the clinical action to be taken, one nurse stated that he did not know how to identify these or what clinical action to take. The other nurses reported that they would request a medical assessment after detecting inflammatory signs in the region of the catheter.

Identification is through the inflammatory signs which the tissue presents, if there was secretion... the 
patient has hyperemia. In relation to what to do, it is a medical procedure, to remove the catheter (I14).

The first clinical action, in the event of suspicion of infection of the implanted port, is to undertake a blood culture from the peripheral access and the central access, so as to identify the site of infection and the microorganism involved, guiding the choice of the antibiotic to be used or the removal of the catheter. ${ }^{8,35,37}$

It should be emphasized that the removal of the catheter is recommended in the event of the persistence of the infection following antibiotic therapy or in the case of detection of infection by Staphylococcus aureus or Candida spp. ${ }^{15,37}$

The use of the catheter after its implantation was also a doubt present in some accounts.

I have doubts about the puncture, whether you can puncture the device as soon as it is implanted, or whether you have to wait a little [...] (I8).

[...] I have doubts about the right time to puncture following the implantation (I24).

Pain is the only limiting factor for puncturing the device soon after its implantation. If the patient is feeling pain which makes the puncture impossible, one must wait for 24 to 72 hours to use it. Should the immediate use of the device be necessary, it must be punctured in the operating room. ${ }^{2}$

\section{The need for standardization of clinical skills}

Although there was no question specifically on the standardization of routines, the need for professional training and for standardization of clinical skills was identified in the nurses' accounts.

[...] For doing the puncture, I don't have any doubts, but the only thing I know about the catheter is to puncture because we - here - have never had any training on the management of this device. (I20).

[...] Actually, we have never had any training on how to proceed with this type of device, we learnt it as we went along, in practice [...] (I12).

I have doubts, because I'm not a specialist in the area, I don't like the area much, and here, as we work in the health clinic, we end up having to deal with the device, but we don't receive any training here, and didn't at college either [...] (I16).

It is believed that the nurses' theoreticalpractical knowledge in relation to the handling of catheters in general is of extreme importance for qualified nursing care and the prevention of com- plications. Academics indicate that this knowledge should be acquired prior to finishing the undergraduate nursing course. ${ }^{20,45}$ Currently, in Brazil, the teaching of oncology and of the puncture technique with this device is not a common practice in the undergraduate courses, which can hinder the clinical practice of professionals integrated into this setting, without prior professional training. ${ }^{46}$

The standardization of clinical skills, based on evidence, through manuals and protocols, is one way of ensuring a qualified clinical practice, as it allows the professionals to settle doubts and guides the undertaking of their actions, offering the professionals greater safety during the undertaking of the procedure. ${ }^{28,43}$

Thus, the development and validation of standard operational procedures are of extreme importance for the improvement of the nursing care, as they direct how to undertake the procedure and offer the nurses greater security.

\section{FINAL CONSIDERATIONS}

From the nurses' accounts it was noted that their knowledge regarding the implanted port is inadequate. This fact is worrying, given that the place where this research was undertaken is a center of excellence in oncology and assists innumerable patients fitted with this device.

The systematized review of the literature indicated a large number of studies classified as having a low level of evidence, which hinders the transposition of findings to clinical practice. It is believed, however, that these results must create - both in the academic community and among the nurses working in the area - interest in undertaking studies whose designs can produce strong evidence, with a view to strengthening the nursing care.

It is concluded, therefore, that there is an urgent need for professional training; and it is hoped that the results presented here may contribute to settling the doubts indicated, affording greater security in the handling of the device and preventing the appearance of complications - which will ensure qualified nursing care and, consequently, better quality of life for the patients attended.

\section{REFERENCES}

1. Gomes IP, Reis PED, Xavier TGM. Cateter venoso central para quimioterapia: problemas e frequência. Rev Eletron Enferm UNIEURO [online]. 2008 JanAbr [acesso 2012 Jan 24]; 2(1):2-21. Disponível 
em: www.unieuro.edu.br/downloads_2009/ reeuni_04_002.pdf.

2. Ministério da Saúde (BR). Instituto Nacional do Câncer. Ações de Enfermagem para o Controle do Câncer - Uma proposta de integração ensinoserviço. 3a ed. Rio de Janeiro (RJ): 2008.

3. Ministério da Saúde (BR). Portaria n. 733 de 14 de outubro de 2002. [online] [acesso 2012 Dez 21]. Disponível em: http://dtr2001.saude.gov.br/sas/ PORTARIAS/PT- 733.htm

4. Rihn TL. Fibrinolytic therapy in central venous catheter occlusion. J Intraven Nurs. 2001;24(3 Suppl):S9-12.

5. Mayo DJ. Catheter-related thrombosis. J Intraven Nurs. 2001; 24(3Suppl):13-22.

6. Bonassa EMA. Administração de antineoplásicos. In: Bonassa EMA, Santana TR. Enfermagem em terapêutica oncológica. $3^{\text {a }}$ ed. São Paulo (SP): Atheneu; 2005.

7. Oliveira SCV. Cateteres totalmente implantáveis em pacientes oncológicos: análise de 178 casos. Arq Catarin Med. 2008 Jan; 37(1):43-8.

8. Vasques CI, Reis PED, Carvalho EC. Manejo do cateter venoso central totalmente implantado em pacientes oncológicos: revisão integrativa. Acta Paul Enferm. 2009; 22(5):696-701

9. Ministério da Saúde (BR). Conselho Nacional de Saúde. Comissão Nacional de Ética em Pesquisa. Resolução n. 196 de 10 de outubro de 1996: diretrizes e normas regulamentadoras de pesquisa envolvendo seres humanos. Brasília (DF): MS; 1996.

10. Bardin L. Análise de conteúdo. São Paulo (SP): Edições Setenta, 2011.

11. Silva CR, Gobbi BC, Simão AA. O uso da análise de conteúdo como uma ferramenta para a pesquisa qualitativa: descrição e aplicação do método. Organ Rurais Agroind. 2005; 7(1):70-81.

12. Reis PED. Uso tópico terapêutico da Chamomilla recutita em flebites decorrentes de terapia intravenosa periférica [tese]. Ribeirão Preto (SP): Escola de Enfermagem de Ribeirão Preto da Universidade de São Paulo; 2008.

13. Melnyk BM, Fineout-Overholt E. Making the case for evidenced-based practice. In: Melnyk BM, FineoutOverholt E. Evidence-based practice in nursing \& health care. A guide to best practice. Philadelphia (US): Lippincott Willians \& Wilkins; 2005.

14. Goossens GA, Stas M, Jérôme M, Moons P. Systematic review: malfunction of totally implantable venous access devices in cancer patients. Support Care Cancer. 2011 Jul; 19(7): 883-98.

15. Vescia S, Baumgärtner AK, Jacobs VR, Kiechle-Bahat M, Rody A, Loibl S, et al. Management of venous port systems in oncology: a review of current evidence. Ann Oncol. 2008 Jan; 19(1): 9-15.
16. Mitchell MD, Anderson BJ, Williams K, Umscheid CA. Heparin flushing and other interventions to maintain patency of central venous catheters: a systematic review. J Adv Nurs. 2009 Oct; 65(10): 2007-21.

17. Debourdeau P, Kassab Chahmi D, Le Gal G, Kriegel I, Desruennes E, Douard MC, et al. 2008 SOR guidelines for the prevention and treatment of thrombosis associated with central venous catheters in patients with cancer: report from the working group. Ann Oncol. 2009 Sep; 20(9): 1459-71

18. Carlo JT, Lamont JP, McCarty TM, LivingstonS, Kuhn JA. A Prospective randomized trial demonstrating valved implantable ports have complications and lower overall cost than nonvalved implantable ports. Am J Surg. 2004 Dec; 188(6): 722-7.

19. Workman ML. Comparison of blot-drying versus air-drying of povidone-iodine-cleansed skin. Appl Nurs Res. 1995 Feb; 8(1): 15-7.

20. Abi-Said D, Raad I, Umphrey J, Gonzalez V, Richardson D, Marts K, et al. Infusion therapy team and dressing changes of central venous. Infect Control Hosp Epidemiol. 1999 Feb; 20(2): 101-5.

21. Kefeli U, Dane F, Yumuk PF, Karamanoglu A, Iyikesici S, Basaran G, et al. Prolonged interval in prophylactic heparin flushing for maintenance of subcutaneous implanted port care inpatients with cancer. Eur J Cancer Care. 2009 Mar; 18(2): 191-4.

22. Bertoglio S, Solari N, Meszaros P, Vassallo F, Bonvento M, Pastorino S, et al. Efficacy of normal saline versus heparinized saline solution for locking catheters of totally implantable long-term central vascular access devices in adult cancer patients. Cancer Nurs. 2012 Jul-Aug; 35(4): 35-42.

23. Arone KMB, Oliveira CZ, Garbin LM, Reis PED, Galvão CM, Silveira RCCP. Obstrução trombótica do cateter venoso central em pacientes submetidos ao transplante de células-tronco hematopoéticas. Rev Latino-Am Enferm. 2012 Ago; 20(4): 804-12.

24. Kuo YS, Schwartz B, Santiago J, Anderson PS, Fields AL, Goldberg GL. How often should a port-A-cath be flushed? Cancer Invest. 2005; 23(7): 582-5.

25. Karamanoglu A, Yumuk PF, Gumus M, Ekenel M, Aliustaoglu M, Selimen D, et al. Port needles: do they need to be removed as frequently in infusional chemotherapy?. J Infus Nurs. 2003 Jul-Ago; 26(4): 239-42.

26. Molin AD, Rasero L, Guerretta L, Perfetti E, Clerico M. The late complications of totally implantable central venous access ports: the results from an Italian multicenter prospective observation study. Eur J Oncol Nurs. 2011 Dec; 15(5): 377-81.

27. Ballarini $C$, Intra M, Pisani Ceretti A, Cordovana A, Pagani M, Farina G, et al.Complications of subcutaneous infusion port in the general oncology population. Oncology. 1999; 56(2): 97-102. 
28. Honório RPP, Caetano JA, Almeida PC. Validação de procedimentos operacionais padrão no cuidado de enfermagem de pacientes com cateter totalmente implantado. Rev Bras Enferm. 2011 Oct; 64(5): 882-9.

29. Gorski LA. Speaking of standards. J Infus Nurs. 2009 Nov-Dec; 32(6): 311-2.

30. Hadaway LC. Tips for using implanted ports safely. Nursing. 2006 Aug; 36(8): 66-7.

31. Larouere E. The art of accessing an implanted port. Nursing. 1999 May; 29(5): 56-8.

32. Larouere E. Deaccessing an implanted port. Nursing. 1999 Jun; 29(6): 60-1.

33. Smith RM. A nurse's guide to implanted ports. RN. 1993 Apr; 56(4): 48-52.

34. Hendrickson ML. How to access an implanted port. Nursing. 1993 Jan; 23(1): 50-3.

35. Arch P. Port navigation: let the journey begin. Clin J Oncol Nurs. 2007 Aug; 11(4):485-8.

36. Walz JM, Stravos GM, Heard EO. Prevention of Central venous catheter bloodstream infections. J Intensive Care Med. 2010; 25(3):131-8.

37. Raad I, Hanna H, Maki D. Intravascular catheterrelated infections: advances in diagnosis, prevention, and management. Lancet Infect Dis. 2007; 7:645-57.

38. Rosenthal K. Guarding against vascular site infection. Nurs Manage. 2006 Apr; 37(4): 54-66.
39. Eisenberg S. Accessing implanted ports: still a source of controversy. Clin J Oncol Nurs. 2011 Jun;15(3): 324-6.

40. Macklin D. Catheter management. Semin Oncol Nurs. 2010 May; 26(2):113-20.

41. Christianson D. Caring for a patient who has an implanted venous port. Am J Nurs. 1994 Nov; 94(11): 40-4.

42. Winslow MN, Trammell L, Camp-Sorrell D. Selection of vascular access devices and nursing care. Semin Oncol Nurs. 1995 Aug; 11(3):167-73.

43. Mendonça KM, Neves HCC, Barbosa DFS, Souza ACS, Tipple AFV, Prado MA. Atuação de enfermagem na prevenção e controle de infecção de corrente sanguínea relacionada a cateter. Rev Enferm UERJ. 2011 Abr-Jun; 19(2): 330-3.

44. Schummer W, Schummer C, Schelenz C. Case report: the malfunction implanted venous access device. $\mathrm{Br}$ J Nurs. 2003 Feb-Mar; 12(4): 212-4.

45. Mlinar S, Malnarsić RR. Knowledge of nursing students about central venous catheters. Vojnosanit Pregl. 2012 Apr; 69(4): 333-9.

46. Amador DD, Coutinho SED, Costa TNA, Collet N. Concepção dos enfermeiros acerca da capacitação no cuidado à criança com câncer. Texto Contexto Enferm. 2011 Jan-Mar; 20(1): 94-101. 